\title{
ASSESSING RELATIONSHIPS BETWEEN LAND USE CHANGES AND THE DEVELOPMENT OF A ROAD NETWORK IN THE HODONÍN REGION (CZECH REPUBLIC)
}

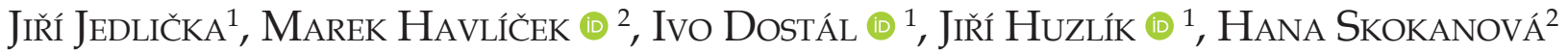 \\ ${ }^{1}$ Transport Research Centre, Brno, Czech Republic \\ ${ }^{2}$ Silva Tarouca Research Institute for Landscape and Ornamental Gardening, Czech Republic
}

Manuscript received: April 18, 2018

Revised version: January 18, 2019

JedličKa J., Havlíčé M., Dostál I., Huzlík, J., SKoKAnová H. 2019. Assessing relationships between land use changes and the development of a road network in the Hodonín region (Czech Republic). Quaestiones Geographicae 38(1), Bogucki Wydawnictwo Naukowe, Poznań, pp. 145-159. 12 figs, 3 tables.

AвSTRACT: The paper assesses the development of land use and a road network from 1836 to 2016 in the Hodonín region (Czech Republic). The aim of the article is to verify relationship between the road construction and land use changes in their vicinity. The intensity of land use change processes between adjacent periods was calculated at various distances from roads. ESRI's geographic information systems and geostatistics were used. This helped in assessing significance of impact of road vicinity on land use changes. The time interval of periods for comparison varied between 25 and 80 years due to availability of historical sources. In each period about $20 \%$ of the region was affected by land use changes. After the roads were built, there was an increase in the intensity of land use changes in their vicinity. It has been proofed that presence of a road can be considered one of the driving forces of long-term land use changes in this region. This so-called technological driving force impacted mainly urbanisation and other anthropogenic processes, agricultural intensification and grassing. Its significance is gradually increasing due to urbanisation, industrialisation, motorization and the rising mobility. Our results from the Hodonín region indicate that urbanisation and other anthropogenic processes have the closest relationship with the distance from major roads.

KEY WORDS: land use, road network, old topographic maps, Hodonín region, Czech Republic

Corresponding author: Marek Havliček, marek.havlicek@vukoz.cz

\section{Introduction}

Transportation and land use are two different aspects of a landscape, but their relationship, despite not being clearly visible, is quite strong. One aspect of this relationship is the direct impact of developing transport networks and accompanying construction on direct land acquisition, and influence on the quality of surrounding soils due to the operation and maintenance of roads and railroads (Mothorpe et al. 2013). However, transportation also impacts land use indirectly. The interaction between the development of both transport and settlement in the past has led to the dynamic growth of settlements on some major transport routes, but may have also significantly impacted smaller settlements in convenient location. At the same time, it is necessary to take into account the attractiveness of administrative or industrial centres specifically for locating nodes of transport networks. As good transport accessibility promotes urban development 
in the vicinity of a road, pressure on acquiring land for new residential and commercial activities increases (Mothorpe et al. 2013). However, there is a strong opposite link as well - the way land is used and developed directly impacts the demand for passenger and freight mobility, hence the pressure for the construction of new or reconstruction of present parts of the transport network.

The historical development of roads based on studying old topographic maps can be used to locate original routes, identify the remains of roads or anthropogenic forms in the landscape, or to document preserved transport objects (parts of roads, bridges, tunnels, milestones, indicators, etc.) and to identify the construction materials used (Ruiz et al. 2014). The historical development of landscapes and their historical structure including old roads, along with both their ecological and cultural significance, have been considered by some authors in planning new roads (Gustafsson 2014).

Long-term changes in land use across Central Europe have been researched with the help of both aerial photographs and old topographic maps. Old topographic maps are usable for analyses of land use changes since approximately the 1840s (Skokanová et al. 2012, Fuchs et al. 2015, Havlíček et al. 2018). At that time, maps from Central Europe (the former Austrian Hungarian Empire and Kingdom of Prussia) started to be based on detailed geodetic surveys and therefore are quite precise.

Studies of long-term land use changes in Central Europe have focused on abiotic conditions (Havlíček, Chrudina 2013, Súl'ovský et al. 2017, Kilianová et al. 2017), landscape protection and ecological networks (Renetzeder et al. 2010, Skokanová, Eremiášová 2013), the development of water bodies (Keken et al. 2015, Pavelková et al. 2016), visual characteristics of landscape (Muchová, Petrovič 2014) as well as the development of the food industry (Havlíček et al. 2013) and other features. As yet, however, there are very few studies linking the long-term development of land use with road networks, even though the development of road networks is considered a major impulse for the further development of settlements and industrial sites. Historical land use was evaluated as a motivation for railway trespassing (Skládaná et al. 2018).
It is well known that land use changes reflect different phases of socio-economic development and political climates, as well as environmental changes (Łowicki 2008). There are five major types of driving forces that have spurred these changes: political, economic, cultural, technological and natural/spatial (Schneeberger et al. 2007, Skokanová et al. 2016, Pazúr, Bolliger 2017). In this categorization, the construction of road networks is a technological driving force, and is mainly associated with the urbanisation that already started in the 19th century due to economic development and a high demand for living space. Urbanisation linked with population growth and the increased spatial mobility of citizens was especially pronounced after the Second World War (Sallay et al. 2012, Kanianska et al. 2014). Economic growth associated with post-war reconstruction and increased industrialisation contributed to the spread of urban areas and the development of the transport infrastructure, which in turn further stimulated urbanisation (Müller et al. 2010). This was caused by progress in technical innovations as well as political decisions to subsidise road construction, as was shown, for example, in a study by Schneeberger et al. (2007). Road construction can also affect agricultural intensification since it enables farmers to reach inaccessible land (Hersperger, Bürgi 2009, Biró et al. 2013). The lack of roads or their deterioration can also lead to the accelerated abandonment of agricultural land (Haase et al. 2007, Łowicki 2008).

The growth of urban agglomerations and accompanying development of transport networks is a very frequent topic when studying relationships between land use and transport networks (Aljoufie et al. 2013, Stanley 2014). Some researchers have also focused on assessing the impact of the construction of highways and other important roads on land use in their vicinity (Müller et al. 2010). Hrejla (2015) explores how steering cultures in local authorities affect implementation of integrated public transport and land use planning. Currently it is a very important topic the integrating of interaction between transport and land use into spatial planning (Colonna et al. 2012, Kii et al. 2016).

The transport geography in the Central European area is studying the relationship between land use changes and transport quite 
rarely. The world-wide review study of Kasraian et al. (2016) does not comprise any paper from this region and even Seidenglanz's (2014) paper on current state of Czech and Slovak transport geography mentions this research agenda only marginally. The following topics can be mentioned in particular: the current processes of suburbanization (Dostál et al. 2010), changes in urban patterns of postmodern cities (Krejčí et al. 2016, Mulíček et al. 2016), integration into spatial and mobility planning (Kortanová et al. 2010, Malasek et al. 2011) or effects on regional development (Kraft et al. 2014, Michniak 2015).

The aim of this article is to assess the development of land use and the transport network in a model region in the Central-European area from 1836 to 2016, to verify the relationship between the construction of roads and land use changes in their vicinity, and evaluate the impact of main roads in the region on land use change processes. Another aim of this article is also to find out whether the construction of roads can be considered one of the driving forces of long-term land use changes occurring in the region.

\section{Study area}

The region of Hodonín is located in southeast Moravia near the border with the Slovak Republic (see Fig. 1) out of agglomeration area of Brno. Its overall area is $1,099 \mathrm{~km}^{2}$, the lowest altitude is $157 \mathrm{~m}$ (near the Morava River) and the highest altitude is $835 \mathrm{~m}$ (in the White Carpathians). Approximately $92 \%$ of the Hodonín region lies at an altitude lower than $400 \mathrm{~m}$ a.s.l. (Havlíček et al. 2013). The region is among the warmest and driest regions in the Czech Republic. Average annual air temperature in the lowlands and hilly lands is about $8-9^{\circ} \mathrm{C}$ and average annual precipitation is $450-550 \mathrm{~mm}$ (Hrnčiarová et al. 2009). Hodonín is one of the most significant agricultural regions

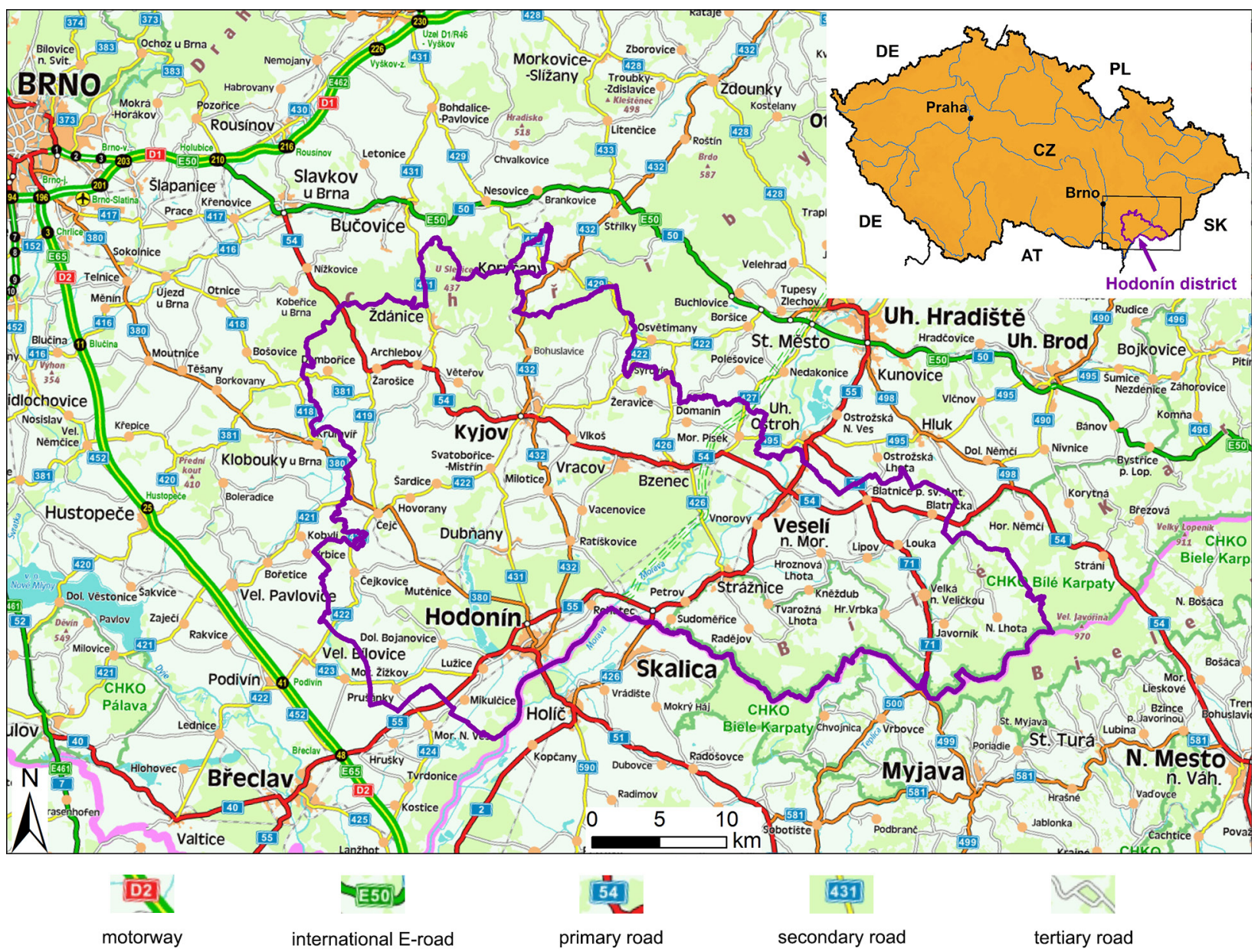

Fig. 1. The Hodonín model region and surroundings with important roads. Source: Czech National Geoportal, CENIA, 2017. 
of the Czech Republic - besides the usual production of cereals and technical crops it also specializes in wine production (Svobodová et al. 2014), which has a strong potential for tourism and recreation (Foret et al. 2014). The largest sources of oil and natural gas in the Czech Republic can be found in the region, and areas around the towns of Dubňany and Kyjov are rich in lignite, which was mined from the beginning of 19th century until 2010. Other mined raw materials include sand and clay, which are often processed by local industrial plants. Besides the food and mining industries, other industrial sectors (e.g. machinery, glass, wood processing, textile, etc.) have developed in the region over the past 200 years. Nowadays, the importance of the industrial centres of Hodonín, Kyjov, Veselí nad Moravou, Bzenec, Dubňany and Ždánice has significantly decreased due to the decline of employment in industry and the closure of a number of industrial enterprises. There are several important roads going through the region that connect towns in the vicinity (Břeclav, Uherské Hradiště, Brno) as well as with towns in Slovakia. A road along the Morava River on the route Břeclav - Hodonín Uherské Hradiště - Otrokovice - Hulín - Přerov - Olomouc has international importance, and was also important in the past as one of the alternative segments of the so-called Amber trail linking important trade centres between the Danube and Baltic regions (Květ 1998).

\section{Material and methods}

\section{Topographic maps}

Land use changes were analysed on the basis of old and contemporary topographic maps using geographic information systems. Five sets of topographic maps were used for analyses that depict the situation in the years of 1840s, 1880s, 1950s, 1990s and 2010s (Table 1). As these sets cover the whole territory of the Czech Republic, the analyses presented here can be reproduced in any other region of the Czech Republic using land use and road data from the same periods.

The tradition of producing topographic military surveys was established in the 19th century during the Austrian Monarchy under the reign of the House of Habsburg, and continued after the establishment of the Czechoslovak state in 1918. Unfortunately due to turbulent times in the first half of the 20th century, results from topographic surveys in this period covered only minor parts of the Czech Republic (Skokanová, Havlíček 2010) and therefore were not usable in this study.

\section{Mapping the road network}

The road network was mapped on the basis of the above-mentioned topographic maps, and included only important roads. In the 19th century, the most important roads were the imperial roads, while since the 20th century the most important roads are termed 1st class roads. Thus, mapping concentrated on imperial (primary) and provincial (secondary) roads that were depicted in the maps from the 2nd and 3rd Austrian Military Surveys, and on roads of 1st (primary), 2nd (secondary) and 3rd (tertiary) class that were depicted on the Czechoslovak military topographic maps and on the Czech topographic base maps (Fig. 2).

\section{Data processing of land use maps}

A total of 9 basic land use categories were evaluated: arable land, permanent grassland, orchard, vineyard and hop-field, forest, water area, built-up area, recreational area and other area (Skokanová et al. 2012).

Analytical digital land use maps were created in ArcGIS software. HawthsTools for ArcGIS was employed to create a hexagonal grid with centroids of the hexagons set to be $100 \mathrm{~m}$ apart,

Table 1. Topographic maps covering the Hodonín region.

\begin{tabular}{|l|c|c|c|}
\hline \multicolumn{1}{|c|}{ Name of the map set } & Scale & Year of publishing & Time period \\
\hline The 2nd Austrian Military Survey & $1: 28,800$ & $1836-1841$ & $1840 \mathrm{~s}$ \\
\hline The 3rd Austrian Military Survey & $1: 25,000$ & 1876 & $1880 \mathrm{~s}$ \\
\hline Czechoslovak military topographic maps & $1: 25,000$ & $1953-1955$ & $1950 \mathrm{~s}$ \\
\hline Czechoslovak military topographic maps & $1: 25,000$ & 1991 & $1990 \mathrm{~s}$ \\
\hline Czech topographic base maps & $1: 10,000$ & 2016 & $2010 \mathrm{~s}$ \\
\hline
\end{tabular}





Fig. 2. Examples of the road network around the town of Veselí nad Moravou on maps from 1841, 1876, 1953, 1991 with the addition of road classification to the map.

Source: State Archive/Military Archive, Vienna, Geoinformatics laboratory, J. E. Purkyně University, Ústí nad Labem, Map collection Faculty of Science, Charles University of Prague, Military Geographic and Hydrometeorologic Office, Dobruška.

creating the area of one hexagon 0.866 ha (Fig. 3). In total, 164,714 polygons were created and only polygons with more than $50 \%$ of their area covering the model region were used for further analyses. Then, the prevailing land use class for

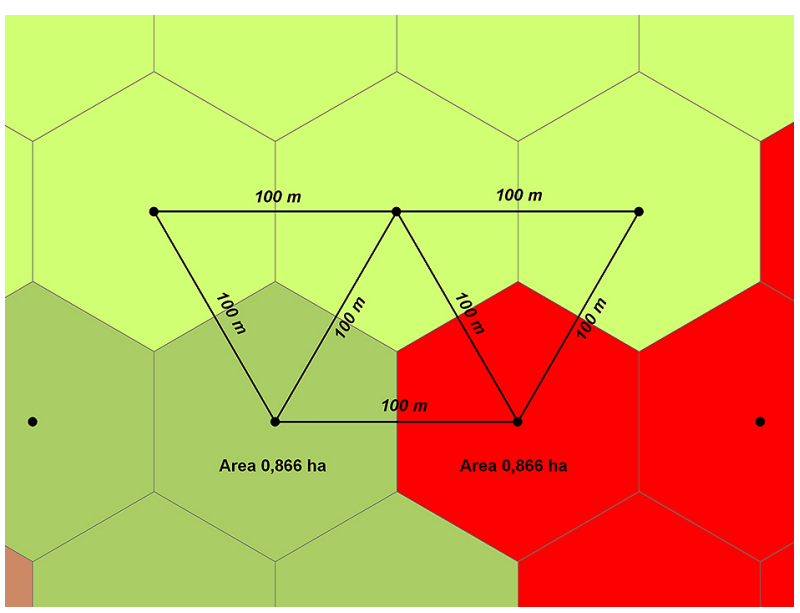

each period was determined for each polygon (Fig. 3). The use of a hexagonal grid for categorizing land use maps enabled generalization in land use interpretation and the removal of land use inaccuracies caused by different map scales

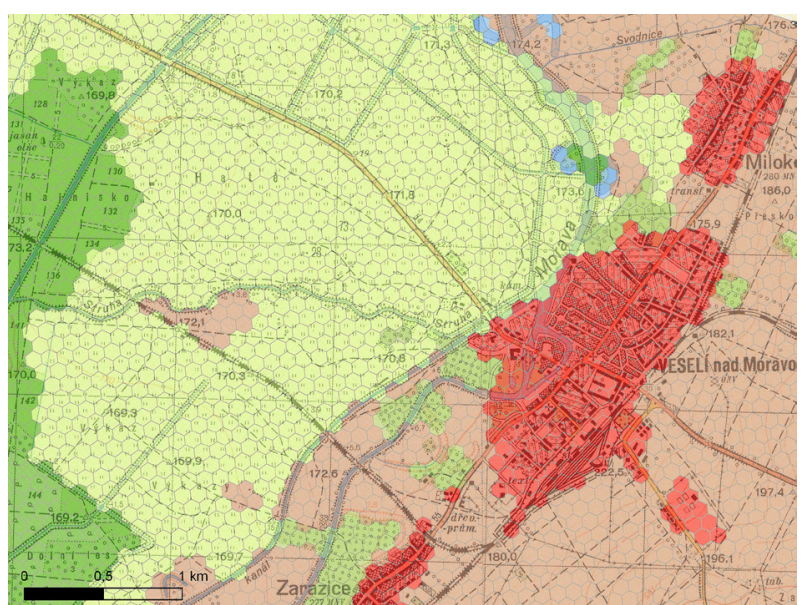

Fig. 3. Example of a hexagonal grid and the interpreted land use map from 1955. 
and positional errors. This helped to avoid the creation of narrow polygons, which often show land use changes that are frequently caused by inaccurate map drawing or interpretation rather than actual changing conditions.

By comparing land use changes between two adjacent time steps, six types of processes were distinguished: afforestation - the conversion of one of the land use categories into forest; grassing - conversion into permanent grassland; agricultural intensification - conversion into arable land, orchard, or vineyard and hop-field; the construction of water areas - conversion into water area; urbanization and other anthropogenic processes - conversion into built-up area, recreational area or other area; and stable areas - no change between the two time steps (Skokanová et al. 2012, Havlíček, Chrudina 2013).

Land use categories as well as land use change processes were assessed at various distances from roads, using the following distance ranges: 0-100 m, 100-250 m, 250-500 m, 500-1000 m, $1000-2000 \mathrm{~m}$, and outside of the vicinity of road network (more than $2000 \mathrm{~m}$ from a road). The assessment of land use development was associated with roads from the same period (i.e. land use from the 1880s corresponded with the road network from the 1880s). When assessing land use change processes in the vicinity of a road network, the process maps were related to the road network from the first assessed period (i.e. land use change processes between the 1840s and 1880 s were related to the road network from the 1840s).

This takes into consideration the hypothesis that significant land use changes could have

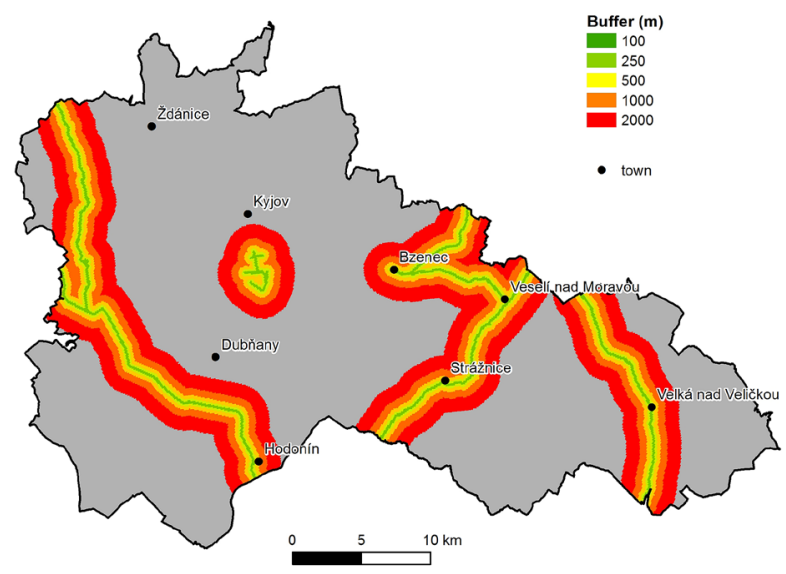

happened along an existing road network. In addition to the simply evaluating the relationship between land use changes and the road network, we also assessed the relationship between the level (class) of a road and associated land use change. For this, roads and their vicinity in each period were divided into three basic categories according to their importance in the given period.

\section{Results}

\section{Development of the transport network}

In general, the total length of the road network significantly increased due to the gradual addition of all road categories. At the same time, the proportion of areas $2000 \mathrm{~m}$ away from the nearest road significantly decreased (Fig. 4).

In the 1840s, the river Morava was a significant natural barrier for roads, predominantly associated with the lack of stable bridge construction in the region. While a railroad from the southwest (town of Břeclav) to northeast (town of Staré Město) led along the right bank of the Morava, the road network connecting the southwest and northeast was developed on the left bank of the Morava. Unlike the present, there was a significant road, categorized as an imperial main road, from the north (town of Veselí nad Moravou) to the south (town of Hodonín) through the important Slovak (then Hungarian) town of Skalica south of the Hodonín region (the middle road in Fig. 4 left). Main imperial roads were also situated in the western part of

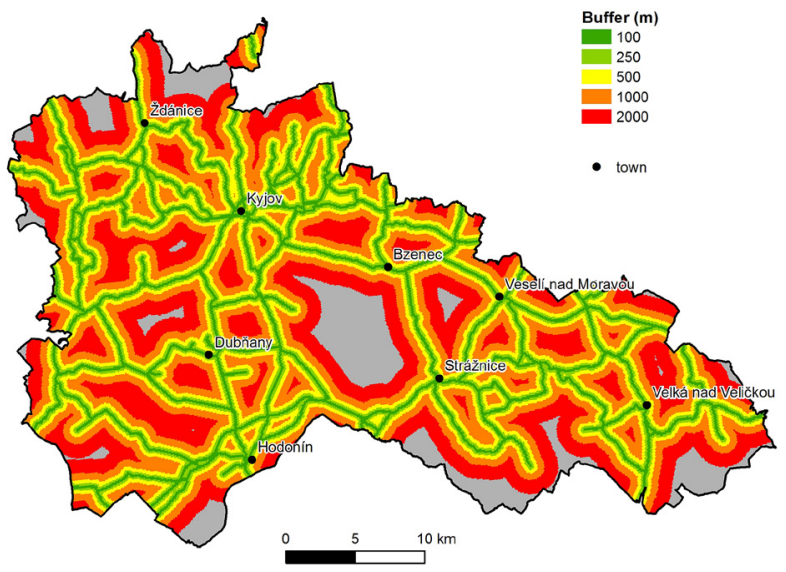

Fig. 4. The road network in the Hodonín region in the 1840s (left) and 2010s (right) with distance zones from a road axis. 
the region. They connected the town of Hodonín with the city of Brno via two different routes one south and one north forking in the village of Čejč near the western border of the region (the left road in Fig. 4 left). Side imperial roads connected towns in the northern part of the region (Bzenec and Veselí nad Moravou). An important provincial road also had a north-south direction, connecting another Slovak (Hungarian) town with towns outside of the region (the rightmost road in Fig. 4 left).

In the 1880s the road network dynamically grew in response to needs for transporting agricultural commodities, building materials, energy materials, industrial products, as well as passengers at both medium and local distances (Table 2 ). The north/south imperial road was still significant. However its route was slightly changed by the building of a bridge across the Morava, which resulted in a weakening importance of routes running through Skalica. Two imperial routes connecting Hodonín with Brno were still major roads. A new imperial road was built from Hodonín to the town of Dubňany, situated northwest of Hodonín and an important mining and glassmaking centre in the region. Another imperial road was built in the western part of the region from the village of Čejč to the town of Břeclav, but this road was not finished. Provincial roads were built mainly in the north-western and eastern part of the region. A route between Hodonín and Břeclav also gained the status of a provincial road.

In the 1950s the proportion of the highest road class in the network (1st class, formerly imperial roads) did not significantly change in comparison to the previous period (Table 2). The importance of the southern route between Hodonín and Brno and the road between Hodonín and Dubňany was reduced, and the north-south road from Čejč to Břeclav became even less important. 2nd class

Table 2. Lengths of road classes in the Hodonín region (in $\mathrm{km}$ ) in the 1840s, 1880s, 1950s, 1990s, and 2010s.

\begin{tabular}{|c|c|c|c|c|}
\hline Road class & Primary & Secondary & Tertiary & Total \\
\hline $1840 \mathrm{~s}$ & 59.5 & 16.8 & 24.6 & 100.9 \\
\hline $1880 \mathrm{~s}$ & 88.3 & 6.4 & 155.0 & 249.7 \\
\hline $1950 \mathrm{~s}$ & 85.2 & 99.3 & 327.8 & 512.3 \\
\hline $1990 \mathrm{~s}$ & 122.1 & 163.3 & 247.8 & 533.2 \\
\hline $2010 \mathrm{~s}$ & 114.4 & 171.8 & 247.8 & 534.0 \\
\hline
\end{tabular}

roads that corresponded to provincial roads from previous periods became more important, predominantly connecting towns and villages in the northern and eastern parts of the region.

Between the 1950s and 1990s the total length of the road network very slightly increased (by about $5 \%$ ) but there were significant changes in the length of roads belonging to different classes. The length of 1 st class roads increased by more than $40 \%$ and the length of 2 nd class roads increased by about $64 \%$ (Table 2) at the detriment of 3rd class roads, which decreased by $25 \%$. These numbers indicate that the basic development of the road network (construction of roads) was finished by the 1950s. Since then the Hodonín region experienced only a slight densification of the road network; however, there were significant changes in the categorization of roads. These changes reflect the turbulent political and economic changes of the period. The qualitative increase in the road network was also enhanced by the gradual increase of motorization connected with the increase in mobility of both goods and people.

Between the 1990s and 2010s basically no new roads were constructed in the region. The only new construction was associated with a roundabout in a village on one 1st class road. Table 1 also shows that no significant changes occurred in the length of road categories. However, a detailed analysis revealed a switch between 1st class and 2nd class roads resulting in a slight decrease in the length of 1st class roads (by 6.3\%).

\section{The development of land use}

The Hodonín region is an important agricultural region in the Czech Republic. The proportion of arable land was highest in all periods (Table 3, Figs 5, 6). Thanks to the agricultural revolution in the second half of the 19th century and the development of the food industry, the proportion of arable land increased to $55 \%$ in the 1880s. A further increase of arable land (by 3\%) in the 1950s was associated with the collectivization of agriculture as a form of agricultural intensification. This occurred not only in lowlands and hilly lands but was also actively practiced in the mountains of the White Carpathians and Chřiby. In most cases, arable land was converted from the original permanent grassland. In the 


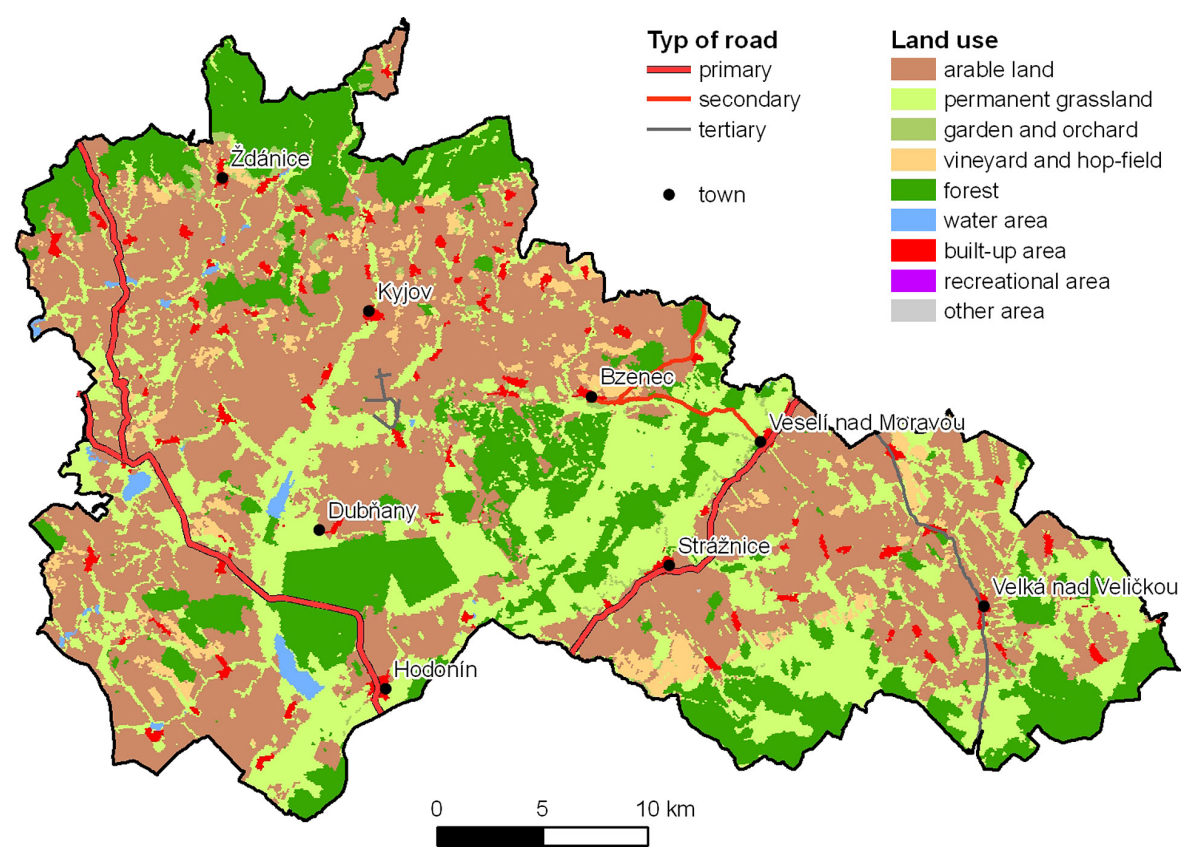

Fig. 5. The road network and land use in the Hodonín region in the 1840s.

later periods (1990s and 2010s) the proportion of arable land declined, predominantly through a transition to built-up areas or large vineyards and orchards.

The largest changes were seen for permanent grassland, where the proportion significantly dropped from $26 \%$ to $7 \%$. Grassland areas were destroyed especially along rivers and in hilly lands (Figs 5,6). Nowadays, the majority of permanent grasslands are situated in the mountains of the White Carpathians, Chřiby and Ždánický les; some meadows and pastures were restored with the help of state subsidies.

The area of forest gradually increased. Forests were found in both lowlands around Hodonín in the south and Bzenec in the north and in the mountains (Table 3, Figs 5, 6). The most significant change connected with forest was associated with the systematic afforestation of a formerly pastoral area around Bzenec that occurred in the second half of the 19th century.

The proportion of vineyards and orchards was highest in the last two periods, and significantly increased in the period of large-scale socialist agricultural management. Water areas were largely drained in the second half of 19th century and turned into arable land. On the other hand, the majority of water areas in the Kyjovka basin (north-western part of the region) have been gradually re-established for fish production. Built-up areas gradually increased (Table 3, Figs 5, 6), and this growth accelerated in the second half of the 20th century. This was associated not only with urbanisation in the cities due to the construction of residential, service, industrial and transportation sites, but also with the growth of villages linked with the construction of agricultural sites. Recreational areas were represented

Table 3. Land use in the Hodonín region (proportion in\%) in the 1840s, 1880s, 1950s, 1990s, 2010s.

\begin{tabular}{|l|r|r|r|r|r|}
\hline \multicolumn{1}{|c|}{ Land use } & $1840 \mathrm{~s}$ & $1880 \mathrm{~s}$ & $1950 \mathrm{~s}$ & \multicolumn{1}{c|}{$1990 \mathrm{~s}$} & $2010 \mathrm{~s}$ \\
\hline Arable land & 45.60 & 54.45 & 57.56 & 51.28 & 50.94 \\
\hline Permanent grassland & 26.24 & 16.66 & 8.71 & 6.48 & 6.85 \\
\hline Garden and orchard & 0.85 & 0.42 & 1.52 & 2.15 & 2.36 \\
\hline Vineard and hop-field & 3.50 & 3.00 & 2.18 & 5.22 & 3.93 \\
\hline Forest & 20.93 & 22.96 & 24.93 & 26.30 & 27.10 \\
\hline Water area & 0.67 & 0.05 & 0.46 & 0.57 & 0.66 \\
\hline Built-up area & 2.21 & 2.44 & 4.49 & 7.53 & 7.68 \\
\hline Recreational area & 0.00 & 0.00 & 0.02 & 0.29 & 0.34 \\
\hline Other area & 0.00 & 0.02 & 0.13 & 0.18 & 0.14 \\
\hline Total & 100.00 & 100.00 & 100.00 & 100.00 & 100.00 \\
\hline
\end{tabular}




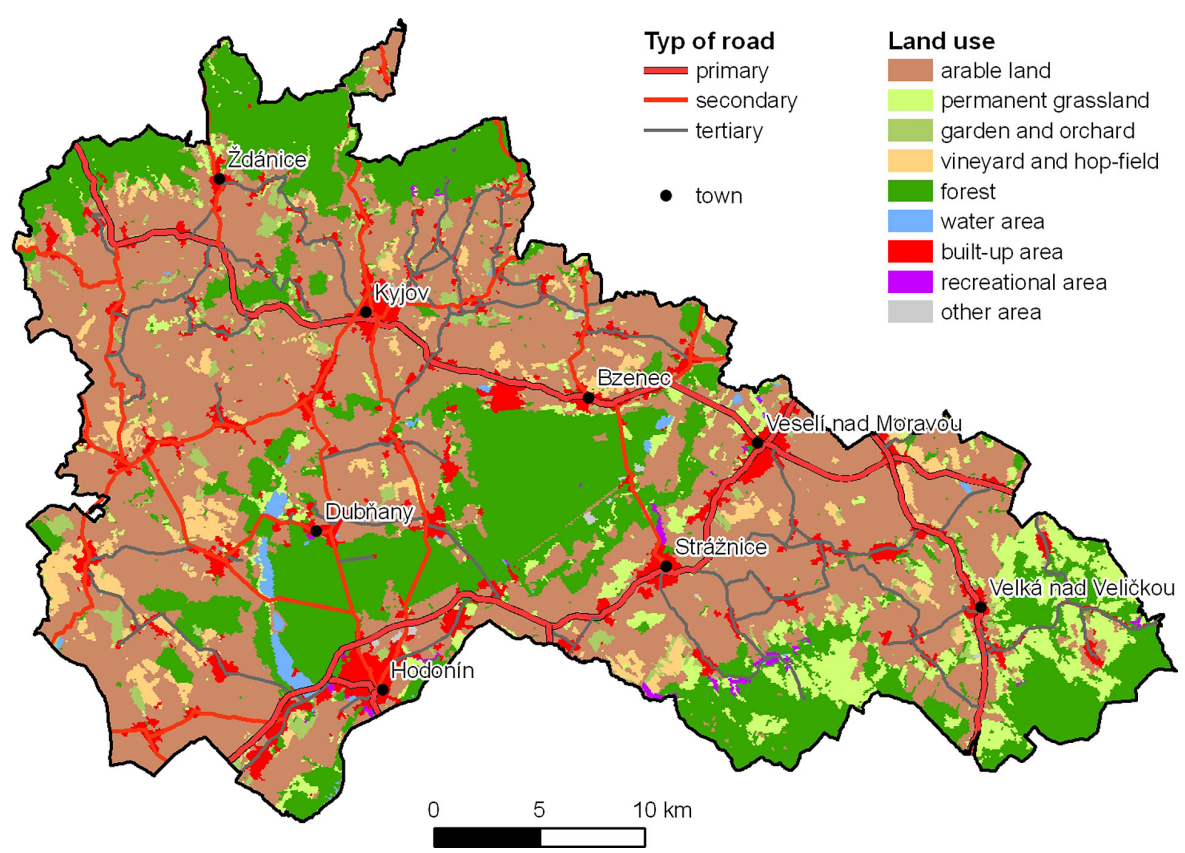

Fig. 6. The road network and land use in the Hodonín region in the 2010s.

by colonies of secondary homes in the foothills of the White Carpathians and Chřiby, and garden colonies in the vicinity of the towns of Hodonín and Kyjov. The proportion of these recreational areas increased especially over the last 20 years. Other areas are mainly associated with sand and clay pits and dump sites.

\section{Land use changes and their relation to the road network}

Land use changes were assessed by using land use change processes. Plots in stable use always significantly prevailed between the periods compared (Fig. 7), with a proportion of about $80 \%$ in the first three periods. The time interval of periods for comparison varied between 25 and 80 years due to availability of historical sources. In each period about $20 \%$ of the region was affected by land use changes. The interval between the last two periods was only 25 years, and yet land use changes occurred in about $12 \%$ of the region.

Agricultural intensification, i.e. conversion to arable land, orchards and vineyards, was always among the most important processes (Fig. 7). Afforestation was also high between the 1840s and 1880s and between the 1880s and 1950s, when it was associated with afforestation of the so-called Moravian Sahara near Hodonín. Urbanisation and other anthropogenic processes dominated during the 20th century (Fig. 7). Besides the construction of residential areas (both family houses and blocks of flats), this was reflected in the construction of agricultural and industrial objects and the establishment of mining sites and dump sites. The intensity of this process decreased in the last twenty years, caused by the economic decline of the region. During the past twenty years the process of grassing slightly increased (Fig. 7), mostly in mountain areas and spurred by state subsidies. The construction of water areas was insignificant from the perspective of the area affected; this process was most significant between the 1880s and

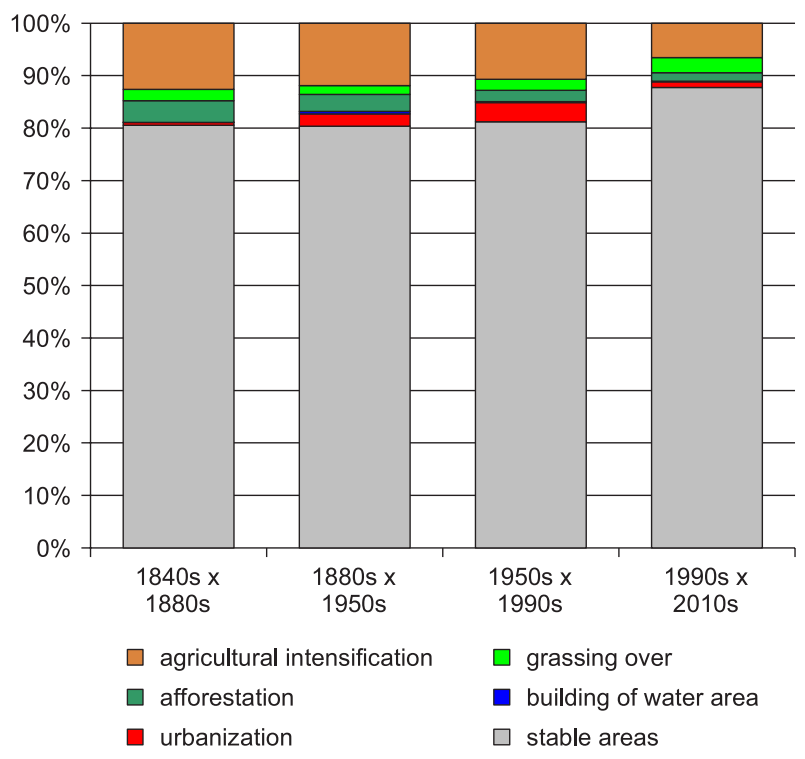

Fig. 7. Land use change processes in the Hodonín region in four comparative periods. 


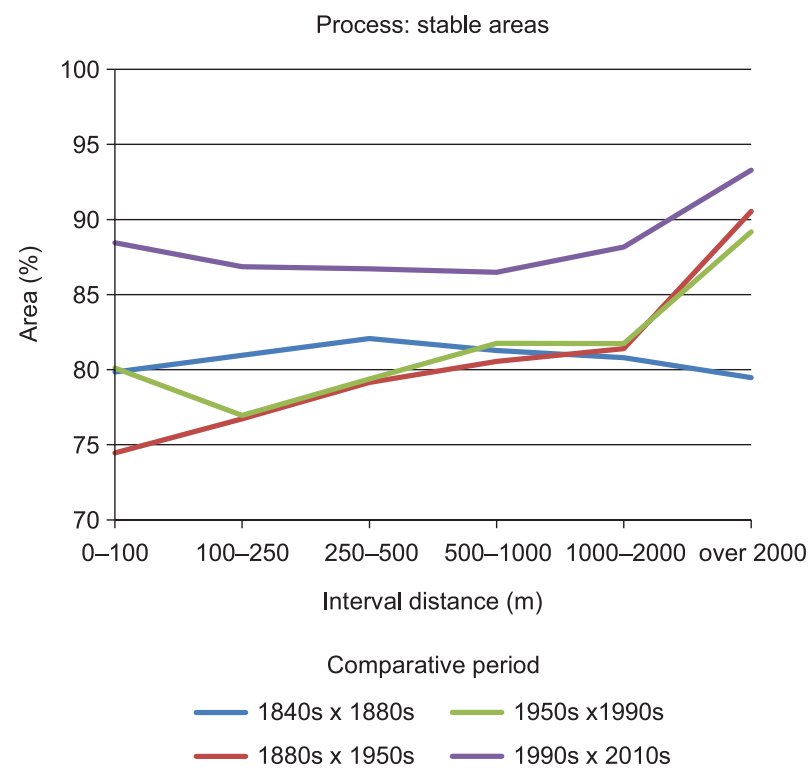

Fig. 8. The proportion (\%) of stably used areas in the Hodonín region at various distances from existing roads.

1950s when a fish pond system was renewed on the river Kyjovka.

Our assessment of the relationship between land use changes and the road network showed that stable areas were situated farther from roads (Fig. 8). Remote localities and inaccessible terrain were covered mainly by forest. The only exception occurred in the 19th century (between the 1840 s and 1880s). In this period, strong agricultural intensification, systematic afforestation and draining of water areas dominated in areas more than $2000 \mathrm{~m}$ away from a road. Stability in the last comparative period was influenced among other factors by the fact that there were stable settlements or stable arable fields near roads, and changes between the 1990s and 2010s were less intensive.

Between the 1840s and 1880s, the importance of a high-quality road network for transport of agricultural goods, namely technical crops for sugar factories, distilleries, mills and other manufacturing industries, was clear. Due to limited transportation options for farmers and food processors in the 19th century, suitable grassland areas in the vicinity of roads were converted to arable land (Fig. 9). This could be observed especially around imperial roads. In later periods the dynamics of agricultural intensification in the immediate vicinity of roads decreased. The second half of the 20th century experienced quite strong

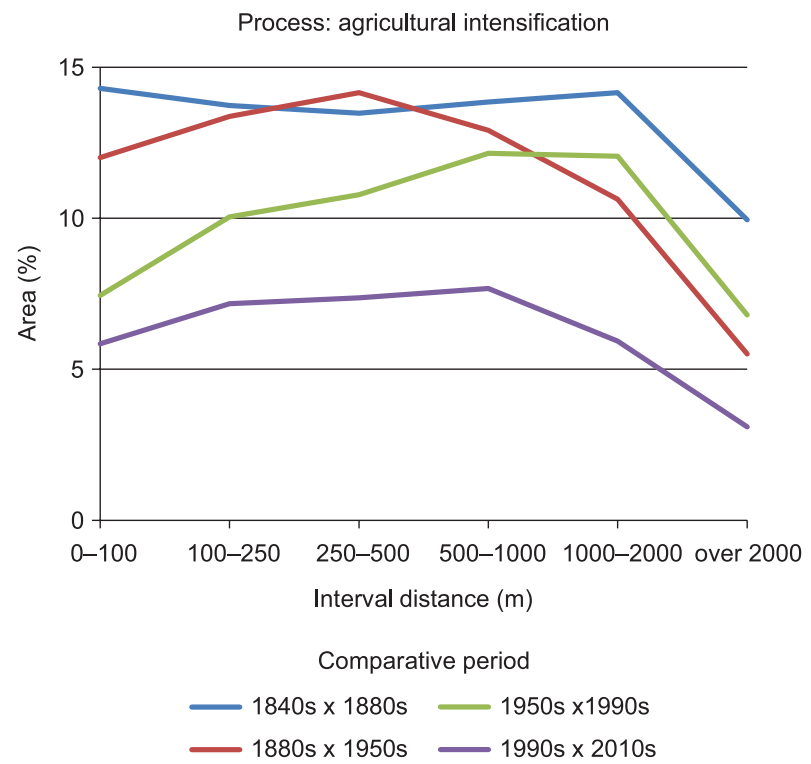

Fig. 9. Agricultural intensification (in \%) in the Hodonín region at various distances from existing roads.

pressure for acquiring new areas with arable land due to the socialist agriculture system associated with political decisions to obtain self-sustained agriculture. This was reflected in the spread of arable land farther from roads and was further stimulated by better accessibility for agronomic equipment (tractors, harvesters). The landscape farthest from roads was usually less attractive for agriculture and therefore agricultural intensification there was mostly avoided.

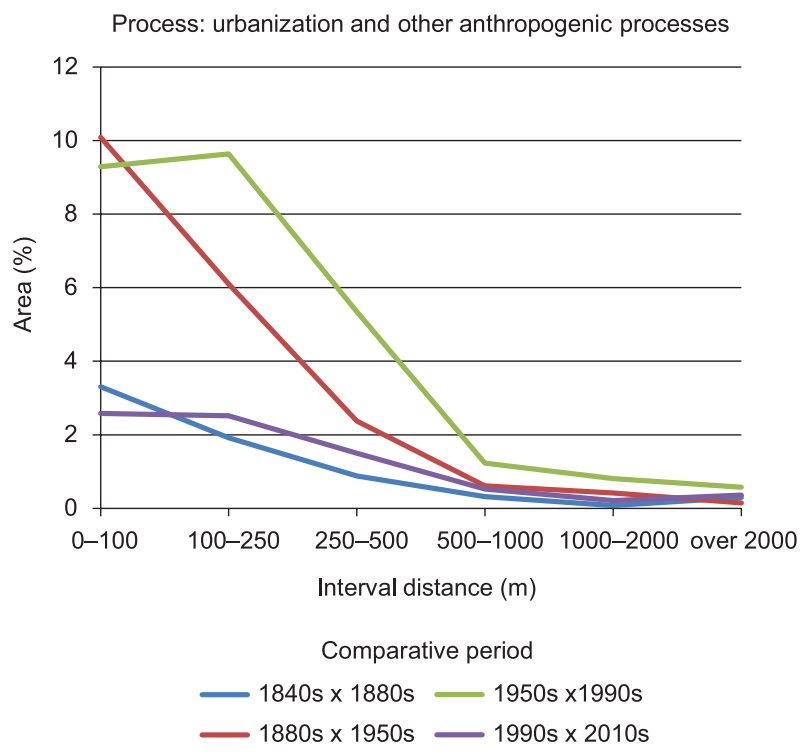

Fig. 10. Urbanisation and other anthropogenic processes in the Hodonín region at various distances from existing roads. 
Urbanisation and other anthropogenic processes were clearly linked with the vicinity of roads, because roads served as a link between settlements, and with the exception of the oldest imperial roads and present highways were systematically routed between individual settlements (Fig. 10). This process was strongly manifested from the end of the 19th century until the end of the 20th century. The tight relationship with the vicinity of roads was associated predominantly with the location of industrial and agricultural sites on the outskirts of settlements, since the distance from a factory to a road was usually a determining prerequisite for building such sites (easy access for transport of goods, less impact on residents, etc.). Dump and mine sites did not require direct connections to high-quality roads and therefore were established in more distant localities.

The localization of main routes (both imperial and provincial roads) together with the localization of crossroads had fundamental impacts on the development of settlements. This was reflected in the spread of settlements along these roads, and in some cases the settlements became linked both physically and administratively. The localization of a settlement on an important crossroad manifested not only in the increase of residential area but also in the construction of new industrial factories and service establishments.

The intensity of afforestation was always higher in more distant parts of the region (Fig. 11). The

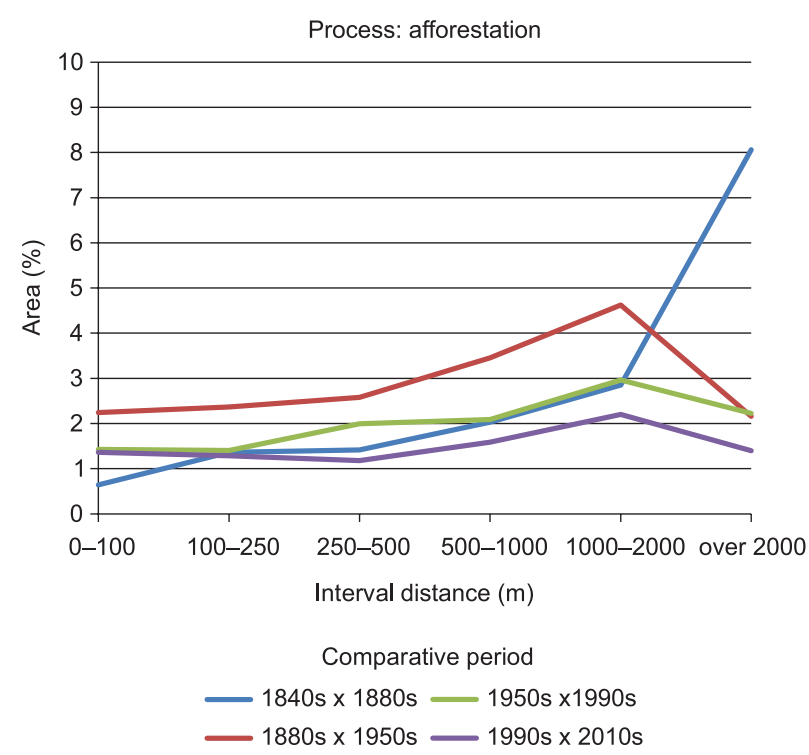

Fig. 11. Afforestation in the Hodonín region at various distances from existing roads.

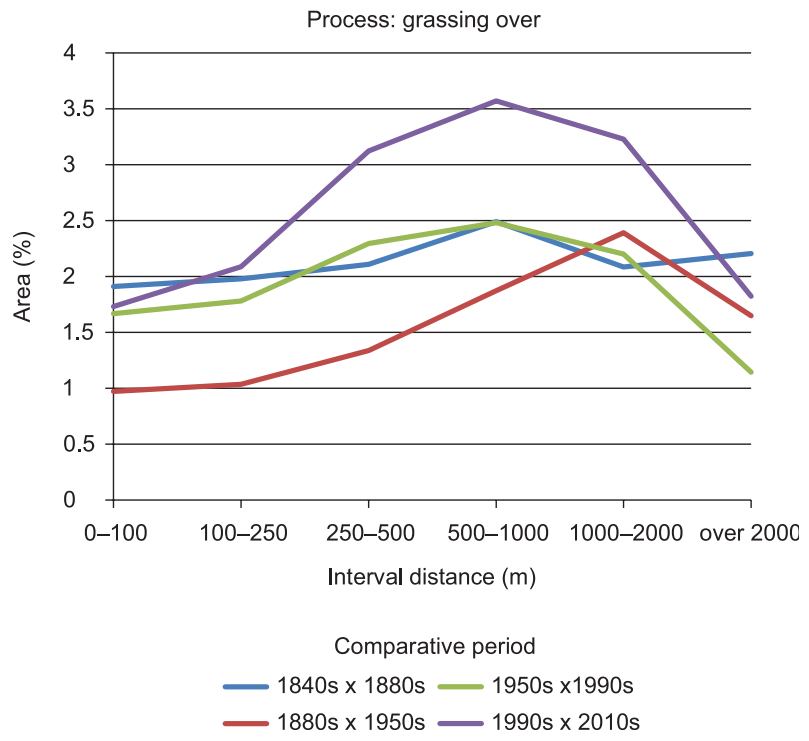

Fig. 12. Grassing in the Hodonín region at various distances from existing roads.

difference was especially pronounced between the 1840s and 1880s when a forest-pastoral area around Bzenec with no significant roads was afforested. In the last twenty years differences in the intensity of afforestation at different distances from major roads were very minor, due to the high density of the road network since the 1990s. Figure 11 also shows a decrease of afforestation in remote areas after 1880 . This was caused by the already-mentioned relative stability of land use in these areas with predominant forests.

The process of grassing was most widespread at intermediate distances from roads (Fig. 12), with mainly the steep slopes of uplands and mountains being grassed. These slopes are generally at intermediate distances from major roads and are accessible predominantly by local roads. The drop in the intensity of grassing in areas more than $2000 \mathrm{~m}$ away from major roads can be again explained by the relative stability of land use in these areas.

\section{Discussion}

The method presented here of using hexagonal grids has been used in geographic studies since the 1930s, first used in Germany in Christaller's Central Place Theory (Von Boventer 1969). For studying land use changes in the Czech Republic they were already used in the 1980s in a case study from South Moravia (Kolejka 1987). The 
principle of hexagonal grids for studying land use changes is also being used currently, e.g. in the works of Terra (2014) or Debnath et al. (2016).

We believe that the main benefit of using a hexagonal grid instead of the simple vectorization of polygons lies in the generalization of individual landscape structures, which minimizes the number of inaccuracies created either during past field surveys or during the digitalization and vectorization of historical map sources. On the other hand, since this method leads to the simplification of landscape structures it can produce inaccurate results that can be crucial at smaller scales, e.g. for the presence and movement of organisms or for some ecosystem services.

Our results from the Hodonín region indicate that urbanisation and other anthropogenic processes have the closest relationship with the distance from major roads. The interaction between this group of land use change processes and the construction of roads, has been confirmed and its importance increases over the long term. The construction of settlements, industrial buildings and sites drives the demand for high-quality transport links via roads and vice versa - the construction of major roads stimulates the construction of settlements and industrial and commercial complexes. The strongest link between urbanisation and roads was found at distances up to $1000 \mathrm{~m}$ from a road, which can be considered as the common distance between built-up areas. The historical importance of road construction was confirmed as one of the driving forces of urban urbanization, the other being the dynamic growth of population in the 19th and 20th centuries. The significance of urbanisation and population mobility connected with the development of motorization in Europe as one of the major driving forces of land use change has also been mentioned by other authors (Kanianska et al. 2014, Sallay et al. 2012). Urbanisation manifested most strongly in the second half of 20th century. This was mainly related to economic development and industrialisation after World War II, and several authors have also mentioned that the development of transport infrastructure further stimulated urbanisation (Müller et al. 2010). The specific relationship between suitable transport infrastructure and built-up areas in the Hodonín region can be documented by the localization of sugar factories, glass factories and other industrial plants near major roads; in many cases their localization instigated improvements of the road infrastructure in their vicinity (Havlíček et al. 2013).

Road construction in the Hodonín region also substantially impacted agricultural intensification. In the first comparative period, between the 1840s and 1880s, the intensity of this process was highest in the immediate vicinity of roads (up to $100 \mathrm{~m}$ ), but was also quite pronounced at other distances up to $2000 \mathrm{~m}$. The availability of high-quality roads in the second half of the 19th century was regarded as an advantage for the transport of technical crops to industrial facilities (namely sugar factories, distilleries and mills), later to the closest railway stations. The importance of good public transport and motivation to convert permanent grassland to arable land has also been documented by the location of scales for weighing agricultural goods directly next to imperial and provincial roads (Havlíček et al. 2013). In the period between the 1880s and 1950s agricultural intensification dominated at the distance $250-500 \mathrm{~m}$ from roads. This was partly due to fact that land in the immediate vicinity of roads had already been used for agricultural purposes, and partly due to strong urbanisation. A decrease of agricultural intensification at distances more than $2000 \mathrm{~m}$ from roads was typical for all periods. Areas at such distances are remote or steep and were therefore used as forests and permanent grassland. Results from the Hodonín region concerning agricultural intensification correspond with those of Schneeberger et al. (2007).

As expected, afforestation was strongest at distances of more than $2000 \mathrm{~m}$. This was caused by both natural conditions (relief, geology, climate, etc.) and the certain remoteness of forests within the spatial organisation of municipalities. Roads with their optimal operational and technical parameters in the predominantly agricultural landscape of the Hodonín region avoided larger forest complexes with the exception of forests in the lowlands. The second half of the 19th century was a specific period with a quite intensive manifestation of this process due to the large-scale systematic restoration of a formerly overgrazed pastoral forest near the town of Bzenec (Havlíček, Chrudina 2013). The impact of roads on the localization of forest complexes was minimal. Interpretation of our results rather reflects spatial 
relationships and links with natural conditions of the region, and our findings are consistent with studies on the impact of abiotic factors on land use in Central Europe (Havlíček, Chrudina 2013, Súl'ovský et al. 2017).

Grassing was less pronounced in this important agricultural region. Restoration of several grasslands occurred after 1990 thanks to state subsidies (Łowicki 2008, Havlíček, Chrudina 2013, Havlíček et al. 2018). The impact of roads on this process was indirect - in the historical context grasslands in the immediate vicinity of roads were ploughed or converted to built-up areas and the process of grassing occurred in areas at intermediate distances from roads (namely 500-1000 m).

Comparisons of the effects of distance from a road on land use stability corresponded with land use change processes. The highest proportion of areas in stable use was mostly found more than $2000 \mathrm{~m}$ from roads. The only exception was at the end of the 19th century due to the already-mentioned restoration of forests near Bzenec that were situated outside of the vicinity of roads. Correspondingly, the smallest proportion of areas in stable use was found in the immediate vicinity of roads where urbanisation and agricultural intensification were most intensive. These findings are in line with general assessments of the distribution of stable areas in a landscape (Skokanová et al. 2012, Súl'ovský et al. 2017).

\section{Conclusion}

Research results confirm that the construction of roads is one of the main driving forces of land use changes. It can be considered a technological driving force (Schneeberger et al. 2007, Skokanová et al. 2016), yet it has also both economic (availability of funds for construction of roads) and political (will of government to subsidise construction) aspects. In the region studied here, this driving force mainly affected urbanisation and other anthropogenic processes, as well as agricultural intensification, and to a lesser extent also grassing and the localisation of stable areas. The importance of this driving force was already seen in the 1840s and gradually increased with the increase of road network density, residential areas, industrialisation, motorization and the transport of goods and later passengers.

The localisation of Hodonín region outside the Brno agglomeration but still on the developmental axis defined by Spatial Policy of the Czech Republic, places it among the semi-rural areas. Therefore, it was possible to observe the processes typical for agglomeration in the small extent only concerning the town of Hodonín with a population of 25000 inhabitants. Due to the absence of motorways or express roads in the area, it is possible to study the potential impact of these types of roads on land use. However, if a planned motorway along the river Morava is constructed such an assessment will become quite attractive.

\section{Acknowledgments}

This paper was produced at the Transport Research Centre with the financial support of the Ministry of Education, Youth and Sports within the National Sustainability Programme I, project of Transport R\&D Centre (LO1610) on the research infrastructure acquired from the Operation Programme Research and Development for Innovations (CZ.1.05/2.1.00/03.0064) and with the help of institutional support from the Silva Tarouca Research Institute for Landscape and Ornamental Gardening (VUKOZ-IP-00027073). The authors are very grateful to the anonymous reviewer for the useful and constructive comments.

\section{Authors' contribution}

J.J., M.H. main writers and completation of text, I.D., H.S. methodological issues + spatial data analysis, J.H. statistics.

\section{References}

Aljoufie M., Brussel M., Zuidgees M., van Maarseveen M., 2013. Urban growth and transport infrastructure interaction in Jeddah between 1980 and 2007. International Journal of Applied Earth Observation and Geoinformation 21: 493-505. DOI: 10.1016/j.jag.2012.07.006.

Biró M., Czúcz B., Horváth F., Révész A., Csatári B., Molnár, Z., 2013. Drivers of grassland loss in Hungary during the post-socialist transformation (1987-1999). Landscape Ecology 28(5): 789-803. DOI: 10.1007/s10980-012-9818-0.

Colonna P., Berloco N., Circella G., 2012. The Interaction between Land Use and Transport Planning: A Methodological Issue. Procedia - Social and Behavioral Sciences 53: 84-95. DOI: 10.1016/j.sbspro.2012.09.862. 
Debnath R., Amin A.T.M.N., 2016. A geographic information system-based logical urban growth model for predicting spatial growth of an urban area. Environment and Planning B: Urban Analytics and City Science 43(3): 580-597. DOI: $10.1177 / 0265813515618565$.

Dostál I., Havlíček M., Huzlík I., 2010. Evaluation of Transport Impact to the Landscape. In: Adamec V., Jandová V. (eds.), IV Czech-Slovak Scientific Conference "Transport, Health and Environment". Blansko, November 2-3, 2010. Brno: Transport Research Centre: 97-104. UT WOS:000392425300013.

Foret M., Konečný O., Klusáček P., 2014. Viticulture - Challenge for Tourism Development (Znojmo Case Study Area). Acta Universitatis Agriculturae et Silviculturae Mendelianae Brunensis 62(2): 339-346. DOI: 10.11118/actaun201462020339.

Fuchs R., Verburg P.H., Clevers J.G.P.W., Herold M., 2015. The potential of old maps and encyclopaedias for reconstructing historic European land cover/use change. Applied Geography 59: 43-55. DOI: 10.1016/j.apgeog.2015.02.013.

Gustafsson M., 2014. Methodology for identifying and assess geo-related ecological and cultural values. In: Seiler A. (ed.), IENE 2014 International Conference on Ecology and Transportation, Programme and Abstracts, Malmö, Sweden, IENE: 121.

Haase D., Walz U., Neubert M., Rosenberg M., 2007. Changes to Central European landscapes-analysing historical maps to approach current environmental issues, examples from Saxony, Central Germany. Land Use Policy 24(1): 248-263. DOI: 10.1016/j.landusepol.2005.09.003.

Havlíček M., Chrudina Z., 2013. Long-term land use changes in relation to selected relief characteristics in Western Carpathians and Western Pannonian basin - case study from Hodonín District (Czech Republic). Carpathian Journal of Earth and Environmental Sciences 8(3): 231-244.

Havlíček M., Skokanová H., Dostál I., Vymazalová M., Pavelková R., Petrovič F., 2018. The consequences of establishing military training areas for land use development - A case study of Libavá Czech Republic. Land Use Policy 73: 84-94. DOI: 10.1016/j.landusepol.2018.01.039.

Havlíček M., Svoboda J., Dostál I., 2013. Vliv rozvoje cukrovarnictví v okrese Hodonín na změny využití krajiny a dopravní infrastrukturu. Listy cukrovarnické a řepařské 129 (9-10): 312-316.

Hersperger A.M., Bürgi, M., 2009. Going beyond landscape change description: quantifying the importance of driving forces of landscape change in a Central Europe case study. Land Use Policy 26(3): 640-648. DOI: 10.1016/j.landusepol.2008.08.015

Hrnčiarová, T., Mackovčin, P., Zvara, J. et al., 2009. Landscape Atlas of the Czech Republic. Ministry of the Environment of the Czech Republic, The Silva Tarouca Research Institute of Landscape and Ornamental Gardening, p.r.i., 332 p.Kanianska R., Kizeková M., Nováček J., Zeman M., 2014. Land-use and land-cover changes in rural areas during different political systems: a case study of Slovakia from 1782 to 2006. Land Use Policy 36: 554-566. DOI: 10.1016/j.landusepol.2013.09.018.

Kasraian D., Maat K., Stead D., van Wee B., 2016. Long-term impacts of transport infrastructure networks on land-use change: an international review of empirical studies. Transport Reviews 36 (6): 772-792. DOI: 10.1080/01441647.2016.1168887.
Kii M., Nakanishi H., Nakamura K., Doi K., 2016. Transportation and spatial development: An overview and a future direction. Transport Policy 49: 148-158. DOI: 10.1016/j. tranpol.2016.04.015.

Kilianová H., Pechanec V., Brus J., Kirchner K., Machar I., 2017. Analysis of the development of land use in the Morava River floodplain, with special emphasis on the landscape matrix. Moravian Geographical Reports 25(1): 46-59. DOI: 10.1515/mgr-2017-0005.

Keken Z., Panagiotidis D., Skaloš J., 2015. The influence of damming on landscape structure change in the vicinity of flooded areas: Case studies in Greece and the Czech Republic. Ecological Engineering 74: 448-457. DOI: 10.1016/j. ecoleng.2014.11.002.

Kolejka J., 1987. Landscape-Historical Synthesis, Materials, Methods and Results. Ekológia Bratislava 6(1): 51-62.

Kortanová J., Jedlička J., Dostál I., 2010. Planning for Sustainable Development of Towns and Villages. In: Adamec, V., Jandová, V. (eds.) IV Czech-Slovak Scientific Conference "Transport, Health and Environment". Blansko, November 2-3, 2010. Brno: Transport Research Centre: 237-242. WOS:000392425300032.

Kraft S., Halás M., Vančura M., 2014. The delimitation of urban hinterlands based on transport flows: A case study of regional capitals in the Czech Republic. Moravian Geographical Reports 22(1): 24-32. DOI: 10.2478/mgr-20140003.

Krejčí T., Dostál I., Havlíček M., Martinát S., 2016. Exploring the hidden potential of sugar beet industry brownfields (case study of the Czech Republic). Transportation Research Part D: Transport and Environment 46: 284-297. DOI: 10.1016/j.trd.2016.04.006.

Květ R., 1998. Trasa jantarové stezky na území Moravy v pravěku i historické době. Vlastivědný věstník moravský 50 (4): 382-387.

Łowicki D., 2008. Land use changes in Poland during transformation: case study of Wielkopolska region. Landscape and Urban Planning 87, 279-288. DOI: 10.1016/j.landurbplan.2008.06.010.

Malasek J., 2011. Greening Warsaw's transport system by sustainable urban planning. WIT Transactions on Ecology and the Environment 155: 267-278. DOI: 10.2495/SC120231.

Michniak D., 2015. Main problems of transport infrastructure development in Slovakia and effects on regional development. Geographia Polonica 88(1): 21-39. DOI: 10.7163/ GPol.0004.

Mothorpe Ch., Hanson A., Schnier, K., 2013. The impact of interstate highways on land use conversion. The Annals of Regional Science 51(3): 833-870. DOI: 10.1007/s00168-0130564-2.

Muchová Z., Petrovič F., 2014. Impact of land consolidation on the visual characteristics (scenery) of a landscape. Journal of Central European Agriculture 15(1): 76-85. DOI: 10.5513/JCEA01/15.1.1414.

Müller K., Steinmeier Ch., Küchler M., 2010. Urban growth along motorways in Switzerland. Landscape and Urban Planning 98(1): 3-12. DOI: 10.1016/j.landurbplan.2010.07.004.

Mulíček O., Osman R., Seidenglanz D., 2016. Time-space rhythms of the city - The industrial and postindustrial Brno. Environment and Planning A 48(1): 115-131. DOI: 10.1177/0308518X15594809.

Pavelková R., Frajer J., Havlíček M., Netopil P., Rozkošný M., David V., Dzuráková M., Šarapatka B., 2016. Historical 
ponds of the Czech Republic: an example of the interpretation of historic maps. Journal of Maps 12: 551-559. DOI: 10.1080/17445647.2016.1203830.

Pazúr R., Bolliger J., 2017. Land changes in Slovakia: Past processes and future directions. Applied Geography 85: 163-175. DOI: 10.1016/j.apgeog.2017.05.009.

Renetzeder C., Schindler S., Peterseil J., Prinz M.A., Mücher S.,Wrbka T. 2010. Can we measure ecological sustainability? Landscape pattern as an indicator for naturalness and land use intensity at regional, national and European level. Ecological Indicators 10(1): 39-48. DOI: 10.1016/j. ecolind.2009.03.017.

Ruiz R., Rodríguez F.J., Coronado J.M., 2014. Identification and assessment of engineered road heritage: A methodological approach. Journal of Cultural Heritage 15(1): 36-43. DOI: 10.1016/j.culher.2013.01.001.

Sallay A., Jombach S., Filepné Kovács K., 2012. Landscape changes and function lost landscape values. Applied Ecology and Environmental Research 10: 157-172. DOI: 10.15666/aeer/1002_15717.

Seidenglanz D., 2014. Transport geography in the Czech Republic and Slovakia. Journal of Transport Geography 41: 350-352. DOI: 10.1016/j.jtrangeo.2014.09.001.

Schneeberger N., Bürgi M., Hersperger A.M., Ewald K.C., 2007. Driving forces and rates of landscape change as a promising combination for landscape change research an application on the northern fringe of the Swiss Alps. Land Use Policy 24: 349-361. DOI: 10.1016/j.landusepol.2006.04.003.

Skládaná P., Havlíček M., Dostál I., Skládaný P., Tučka P., Perůtka J. 2018. Land use as a motivation for railway trespassing: Experience from the Czech Republic. Land 7(1): art. no. 1, DOI: 10.3390/land7010001.

Skokanová H., Havlíček M., 2010. Military topographic maps of the Czech Republic from the first half of the 20th Cen- tury. Acta Geodaetica et Geophysica Hungarica 45(1): 120 126. DOI: 10.1556/AGeod.45.2010.1.17.

Skokanová H., Eremiášová R., 2013. Landscape functionality in protected and unprotected areas: Case studies from the Czech Republic. Ecological Informatics 14: 71-74. DOI: 10.1016/j.ecoinf.2012.11.007.

Skokanová H., Havlíček M., Borovec R., Demek J., Eremiášová R., Chrudina Z., Mackovčin P., Rysková R., Slavík P., Stránská T., Svoboda J., 2012. Development of land use and main land use change processes in the period 1836-2006: Case study in the Czech Republic. Journal of Maps 8(1): 88-96. DOI: 10.1080/17445647.2012.668768.

Skokanová H., Falt'an V., Havlíček M., 2016. Driving forces of main landscape change proceses from past 200 years in Central Europe - Differences between old democratic and post-socialist countries. Ekologia Bratislava 35(1): 50-65. DOI: 10.1515/eko-2016-0004.

Stanley J.K., 2014. Land use/transport integration: Starting at the right place. Research in Transportation Economics 48: 381-388. DOI: 10.1016/j.retrec.2014.09.067.

Súlovský M., Falt́an V., Skokanová H., Havlíček M., Petrovič F., 2017. Spatial analysis of long-term land-use development in regard to physiotopes: case studies from the Carpathians. Physical Geography 38 (5): 470-488. DOI: 10.1080/02723646.2017.1318652.

Svobodová I., Věžník A., Král M., 2014. Viticulture in the Czech Republic: Some spatio-temporal trends. Moravian Geographical Reports 22 (1): 2-14. DOI: 10.2478/mgr-20140001.

Von Boventer E., 1969. Walter Christaller's Central Places and Peripheral Areas: The Central Place Theory in Retrospect. Journal of Regional Science 9: 117-24.

Terra T.N., dos Santos R.F., Costa, D.C., 2014. Land use changes in protected areas and their future: The legal effectiveness of landscape protection. Land Use Policy 38: 378-387. DOI: 10.1016/j.landusepol.2013.12.00. 